\title{
Возможна ли социология для трудящихся классов сегодня?
}

\author{
Т.С. ЛЫТКИНА*, С.С. ЯРОШЕНКО**
}

\begin{abstract}
*Татьяна Степановна Лыткина - кандидат социологических наук, старший научный сотрудник, Институт социально-экономических и энергетических проблем Севера Коми НЦ УрО РАН. Адрес: 167982, Сыктывкар, ул. Коммунистическая, д. 26. E-mail: tlytkina@yandex.ru

**Светлана Сергеевна Ярошенко - кандидат социологических наук, доцент, кафедра сравнительной социологии, факультет социологии, Санкт-Петербургский государственный университет. Адрес: 191124, Санкт-Петербург, ул. Смольного, д. 1/3. E-mail: svetayaroshenko@gmail.com
\end{abstract}

Цитирование: Лыткина Т.С., Ярошенко С.С. (2019) Возможна ли социология для трудящихся классов сегодня? // Мир России. Т. 28. № 1. С. 101-123. DOI: $10.17323 / 1811-038 X-2019-28-1-101-123$

В статье анализируются возможности приращуения сощиологического знания о росте сочиального неравенства через изучение трудящихся и прежде всего рабочего класса, вынужденного продавать рабочую силу в условиях снижения статуса. Через обращение к истории социологической мысли рассматривается значимость категории социального класса для становления сочиологии как науки. Данный тезис также проводится через анализ особенностей развития российской социиологии в дореволюичинный и советский периоды. Выделяется не только отличительная черта российской сочиологии - противостояние власти и ученых, - но и доказываются маловероятность эволючии общества без социологии и проблематичность развития социологии без общества и знания о его классообразующих механизмах. Настоящее состояние российской социологии характеризуется как инволюционное, связанное с замыканием сочиологов на своих интересах и противоречиях. В то время как в условиях глобализаџии рынка идет поиск компромисса между разными классами и требуется новое обращение к рабочему классу, российские сочиологи предпочитают творить сочиологию, пренебрегая интересами рабочих. Доказывается, что исследование текущиих процессов в обществе исходя из перспектив рабочего класса способствует сокращзению противоречий и может быть полезно как при реконструкции устаревших теорий, так и в разработке новых подходов. Это требует не только объединения усилий сочиологов в продвижении внутренней критики, но и развития публичной сочиологии, способствующей диалогу с обществом и лучшему пониманию происходящего. 
Ключевые слова: рабочий класс, трудящиеся, критическая социология, публичная социология, феминистский анализ, социологический марксизм, теория социального исключения

Замысел статьи возник в процессе организации и проведения панельной дискуссии $^{1}$ о перспективах социологии в целом и российской социологии в частности. Первоначально для обсуждения был предложен вопрос о возможностях современной социологии для рабочего класса, которые расцениваются как потенциал социологического знания, сфокусированного на изучении социального неравенства через призму рабочего класса, вынужденного продавать рабочую силу в условиях снижения статуса. Какие перспективы открывает социология при изучении социальной реальности в условиях глобализации? Зачем нужна социология в России? Каково ее будущее? И что может дать изучение рабочего класса?

Такая постановка вопросов основывалась на идее М. Буравого о необходимости развития публичной социологии, ориентированной на неакадемическую аудиторию и обсуждение целей и задач, которые стоят перед социологами. Эту мысль он обсуждал с российскими социологами еще в 2008 г., находясь на посту президента Международной социологической ассоциации. Для авторов настоящей статьи возвращение к этой идее в 2015 г. представляло собой рефлексию по поводу возможностей социологии объяснить происходящее в российском обществе, ответить на социальные запросы и продемонстрировать интересы тех социальных слоев, которые вытесняются на периферию вместе с глобальным рыночным развитием. Между тем формулировка темы дискуссии о рабочем классе вызвала споры, и мнения по поводу того, к кому и с какими вопросами следует обращаться, разделились. Высказывались как поддержка, так и сомнения относительно уместности такой постановки проблемы. Оказалось не так просто откликнуться на призыв и выдержать вызов - различными способами объединить усилия исследователей и разных слоев российского общества, в том числе той его части, которая всегда находилась в фокусе внимания М. Буравого. Его профессиональная карьера была тесно связана с изучением положения рабочего класса в разных странах. У него не было сомнений в необходимости его изучения в России даже тогда, когда эпицентром экономической активности стали домохозяйства. Для нас обращение к публичной социологии было вызвано потребностью обсудить изменения, происходящие в российском контексте как внутри, так и за рамками социологического общества, с возможностью провести ревизию того, что уже известно российским социологам о результатах реализации рыночных реформ и их влиянии на положение различных социальных слоев и всего общества. Это явилось стимулом для осознания, что снижение статуса социологии обусловлено утратой чувствительности к тому, что означают продажа рабочей силы на унизительных условиях, борьба за средства существования в расколотом обществе и игнорирование требований «снизу».

В статье будут рассмотрены не только необходимость разворота от «рабочих» к «трудящимся», но и вопросы кооперации внутри социологического сообщества.

1 Дискуссия состоялась 24 марта 2015 г. в Санкт-Петербургском государственном университете в рамках визита М. Буравого, профессора социологии Калифорнийского университета США. 
Через призму развития социологии как науки и анализа современной российской ситуации была сделана попытка показать, насколько отчетливо проявляется тенденция замыкания социологов в своих интересах и противоречиях, когда в столкновении с нестабильной ситуацией вместо детального изучения причин и природы растущего социального неравенства ученые заняты его конструированием. На примере социологического сообщества можно наблюдать более ранние процессы «Великой инволюции в России», т.е. замыкания общества в самом себе, и то, как действуют механизмы исключения. В отличие от М. Буравого, стремящегося найти поддержку у общества, российские социологи, освободившись от идеологии марксизма-ленинизма, уже не ищут поддержки ни общества, ни своих коллег. Примеряя на себя международные стандарты и рейтинги, они (как и обычные граждане) поддерживают процессы исключения в системе науки и образования, разрушают профессиональное сообщество, так и не приобретя высокий уровень профессионализма.

Статья состоит из четырех частей. Сначала будет проанализированы значимость обращения к рабочему классу и вклад категории класса в становление социологии как науки. Через историю формирования социологии в разных странах акцентируется потребность самой науки в обращении к рабочему классу, к проблемам социального неравенства и построения справедливого общества; именно эта потребность способствует ее развитию. Благодаря науке меняется и само общество, что будет продемонстрировано во второй части через специфику представительства интересов угнетенных в российской социологии в дореволюционный и советский периоды с упором на проблемы противостояния власти и ученых, преимуществ критической рефлексии при анализе реального положения рабочего класca. В третьей части на основании обзора ключевых тем в исследованиях периода рыночных реформ 1990-х гг. в России анализируются последствия утраты критичности по отношению к рынку, его негативному влиянию на положение наемных работников и неравное распределение рыночных благ и шансов. Будет показано, что ухудшение положения рабочего класса ведет к ослаблению социальных позиций других слоев, поскольку запущенный рыночный механизм распространения зоны уязвимости действует постепенно и незаметно. Наконец, в четвертой части рассматриваются дискуссионные вопросы в теоретическом осмыслении глобализации рыночных отношений и обсуждается необходимость возвращения к рабочему классу не только как объекту исследований, но и как субъекту социальных изменений. Совокупность этих процессов представляется в качестве возможностей социологии для трудящихся классов.

\section{Рабочий класс и становление социологии}

Становление социологии как самостоятельной науки невозможно без понимания важности изучения социальных классов в научном представлении общества как целостной системы, состоящей из различных элементов, и в то же время как системы, меняющейся в силу быстрого развития капиталистической формации и нарастающей динамики социальных конфликтов. Именно это обстоятельство - реальное и осязаемое наличие общественного класса - потребовало не только 
социально-философского, но и «позитивно-политического» (тезис Конта) объяснения социальных феноменов. Неслучайно и то, что социология возникла в экономически и культурно развитых странах Западной Европы XIX в. - Франции, Англии, Германии, где были заложены основы раннего буржуазного общества; формировалась по-новому дифференцированная структура общества; определялись механизмы его развития, воспроизводства и изменения. На арену активной общественной жизни вышли иные социальные силы или субъекты, в том числе массовые (профессиональные союзы трудящихся, политические партии и движения), которые нуждались в ясном понимании сложных, подчас революционных процессов [Лапин 2004, с. 14]. Общество также нуждалось в знании о способах разрешения конфликтов, и социологи оказались чувствительными к социальным вопросам, уловив запрос «снизу».

С распространением рынка и разрушением сословного общества различные конфигурации общественных сил внутри и вне страны влияли не только на происхождение капитализма, но и на взгляды ученых относительно движущих сил социальных изменений. Закономерно, что французская социология отличалась высокими амбициями, непременным обращением к противоречиям между классами и сочувствием классу «отверженных». Примечательно, что для французских социологов интерес к религии был ведущим, т.е., претендуя на позитивизм, они исходили из субъективизма, вплоть до выделения интеллектуалов в особый класс ${ }^{2}$, и только профессиональные каноны сформированной науки привели к практическому «отказу от самих себя» (от своей субъективности) и обращению к классам. Для английской социологии были характерны основательность, выведение естественных законов социальной жизни: британские социологи ратовали за эволюционный, постепенный и длительный путь развития через согласование разных интересов внутри классов, а не межклассовый конфликт, и здесь отношение к рабочему классу было невероятно уважительным. Немецкая социология формировалась на основе критики по отношению к системе: здесь возникли идеи динамики общества, социального государства, конкурентной способности трудящихся; укоренилось видение в отдельных элементах общества действия системы в целом. Американская социология изначально стремилась развить науку об обществе таким образом, чтобы сделать политику ненужной${ }^{3}$. Наука не должна была решать социальные проблемы, а призвана создавать условия для улучшения ситуации через понимание устройства социальной организации, однако из-за стремления во что бы то ни стало сохранить капиталистическую систему, устранить конкурирующие представления о ней она становилась наивной. Уверенность первых американских социологов в превосходстве ценностей «свободного рынка», «равных возможностей», «открытого общества» обусловила как привлекательность «культурных» объяснений производства бедности, так и упорную защиту рынка и либеральных ценностей. Научная теория использовалась для того, чтобы доказать положение, согласно которому корни преступности заключаются не в социально-бытовых условиях, а в неких «генах преступности» [Вудс, Грант 2015, с. 37],

\footnotetext{
2 Интеллектуалы представлялись «особым классом», посвятившим себя регулярной научной деятельности [Давыдов 1994, с. 56].

3 И могла себе это позволить, «потому что была избавлена от необходимости предоставления немедленных практических результатов и рекомендаций» [Буравой 1991, с. 74].
} 
т.е. в самом человеке. Подобная предвзятость стала следствием оторванности от запросов со стороны общества; эта же автономия и приверженность принципам беспристрастного исследования впоследствии позволили опровергнуть заблуждения и даже получить признание со стороны американских граждан. В конечном счете пришлось признать, что производство знания исходя из иерархического упорядочивания ценностей не решало проблем общества, а вело к представительству групповых интересов, тогда как росту профессионализма социологов способствовали критический взгляд на общество, развитие различных подходов и относительная автономия социологов от рекомендаций заказчикам (будь то правительству или бизнесу), а также непременное возвращение обществу обогащенного, узнаваемого и понятного социологического знания.

Следует подчеркнуть, что само общество трактовалось по-разному: как состояние согласия (О. Конт) или как социальный организм, сочетающий дифференциацию с интеграцией в ходе естественной эволюции его социальных институтов (Г. Спенсер), или как объективная совокупность институтов, определяющих тип солидарности (Э. Дюркгейм), или как органическая система, достигающая целостности через классовую борьбу и революцию (К. Маркс). Но как бы оно ни представлялось, требовалось изучение представителей различных слоев, всех видов общностей и обществ, основу которых составляет взаимодействие людей, движимых волей (Ф. Теннис). Важно также отметить, что классики социологии, озадаченные противоречиями общественного развития периода раннего капитализма, пристальное внимание уделяли категории «класс». В обоснованиях исторической миссии рабочего класса или в ее резкой критике в качестве движущих сил общественного развития предлагались менее радикальные и разрушительные альтернативы: например, культура и образование, т.е. просвещение и формирование рабочей аристократии и государства (М. Вебер), или органическая солидарность (Э. Дюркгейм). В каждом случае речь шла о возможностях достижения более справедливого общественного устройства, а продуктивность аналитической категории «класс» проверялась теоретически через публичную критику каждой позиции. Наконец, с самого начала, с 1880-х гг. вплоть до Первой мировой войны, в фокусе особого внимания находилась разработка методологии социологических исследований, т.е. способов производства научного знания и организации научной деятельности: как выстраивать отношения с «объектом», получать надежные данные, создавать теорию и проверять ее на практике.

Классики социологии спорили относительно движущих сил развития общества и стремились предложить системное видение общества XIX в. для объяснения явлений, происходящих в нем. Несмотря на разные теоретические позиции, рабочий класс принимался ими во внимание в качестве значимого элемента общественного устройства, изучение которого становилось инструментом достижения социальной справедливости и развития самой социологии.

\section{Социиология в России: крайности оппозициий}

В царской России, по существу, аграрной стране с традиционным крестьянским укладом жизни, становление социологии оказалось сложным: ей постоянно 
приходилось быть в оппозиции: сначала к царскому режиму ${ }^{4}$, затем - к советской власти ${ }^{5}$. Российских интеллектуалов, обеспокоенных перспективами развития российского общественного строя, отличали осознание несправедливости, субъективизм и критика власти.

Теоретический каркас российской социологии выстраивался через интерпретацию зарубежной социологии, совмещение образовательной деятельности с просветительской, участие в стремительно развивающихся общественных движениях (либеральном, феминистском, рабочем). В работах ученых поднимались актуальные вопросы, как то: общинное землевладение, национальный и рабочий вопросы, политические доктрины демократии и монархии (М.М. Ковалевскийб), психология кооперативов как договорных социальных объединений (В.М. Хвостов $^{7}$ ), нравственные основы социального взаимодействия (П. Сорокин ${ }^{8}$ ) и специфика рабочего движения (К.М. Тахтарев ${ }^{9}$ ). Увлечение систематизацией собственных идей неизбежно порождало разномыслие, и приходилось обращаться к трудам западных коллег, чтобы совместить теоретические выкладки с российской действительностью ${ }^{10}$.

Эмпирическая проверка теоретических рассуждений проводилась по остаточному принципу: на нее просто не хватало ни времени, ни сил, а иногда и желания. Внутренняя критика также была ограничена в силу идейной пристрастности и определенной политизированности. Примечателен тот факт, что первые российские социологи являлись достаточно состоятельными людьми, но их отличали сочувствие «униженным и оскорбленным», глубокое эмоциональное напряжение по поводу вопиющих условий труда рабочих и зреющего недовольства, а также обеспокоенность последствиями снижения статуса дворянства вслед за утратой привилегий на свободу, т.е. фактически принуждением к оплачиваемой работе. Это касалось и женщин разных сословий, представлявших собой экономически зависимый и бесправный слой, и либерально настроенные и вполне состоятельные «равноправки» готовы были решать вопросы женщин из рабочей среды [Юкина 2007, с. 270-280].

\footnotetext{
4 В 1887 г. М.М. Ковалевский был уволен с профессорской должности Московского университета в виду «отрицательного отношения к русскому государственному строю» и почти 18 лет провел за границей [Голосенко 1995, c. 4-5]. В 1911 г. другой представитель русской традиции в социологии В.М. Хвостов сам покинул Московский университет в знак протеста против царской бюрократии, ограничивающей угрозами исключения из университетов участие студентов в самодеятельных организациях и митингах [Голосенко 2002, с. 65].

5 В 1922 г. на так называемом философском пароходе по инициативе В.И. Ленина в рамках борьбы с инакомыслием за пределы Советской России были высланы оппозиционно настроенные представители интеллигенции (в том числе П. Сорокин).

6 См.: Ковалевский М.М. (1879) Общинное землевладение, причины, ход и последствия его разложения. М.: тип. Ф.Б. Миллера; Ковалевский М.М. (1895-1897) Происхождение современной демократии. Т. 1-4. М.: типография товарищества А.И. Мамонтова; Ковалевский М.М. (1906) От прямого народоправства к представительному и от патриархальной монархии к парламентаризму. Т. 1-3. М.: типография товарищества И.Д. Сытина.

7 См.: Хвостов В.М. (1919) Психология кооператива // Вестник промысловой кооперации. № 1.

8 См.: Сорокин П.А. (2006) Преступление и кара, подвиг и награда: Социологический этюд об основных формах общественного поведения и морали. М.: Астрель.

9 См.: Тахтарев К.М. (1906) Очерк петербургского рабочего движения 90-х годов. По личным воспоминаниям. СПб.: Новый мир.

10 Например, в своих работах М.М. Ковалевский сознательно делал упор на обзоре зарубежной социологической мысли, считая важным такого рода просветительство из-за малодоступности подобных знаний в России.
} 
Между тем социальные процессы, вызванные становлением капитализма, требовали независимого и системного анализа положения общественных классов. На повестке дня стояли вопросы роста численности рабочих в городах, тесной связи с деревней, сезонной мобильности, низкой заработной платой, дефицита воспроизводства рабочего класса (что в свою очередь увеличивало отток рабочей силы из деревни), необходимости научной организации труда с целью повышения его производительности. Все вышеперечисленное предполагало беспристрастные теоретические и эмпирические исследования реального положения классов, при том что царское правительство не проявляло заинтересованности в таком знании. Показателен тот факт, что русская школа общественных наук, созданная по инициативе М.М. Ковалевского в 1900 г. в Париже, была впоследствии закрыта (под угрозой лишения гражданства и конфискации имущества вынужденных и добровольных мигрантов) и вновь начала функционировать в Санкт-Петербургском Психоневрологическом институте только в 1908 г. [Голосенко 1995, с. 6].

Несмотря на пассивность рабочего класса, неразвитость производительных сил, идея К. Маркса о разрушении частной собственности и внедрении социалистических принципов производства была воплощена именно в России. Динамичные изменения в обществе, последовавшие за Октябрьской революцией 1917 г., вновь требовали объединения усилий обществоведов, но противостояние между марксистскими и немарксистскими социологами закончилось высылкой оппозиционеров за рубеж и последующими репрессиями в отношении оставшихся. Иными словами, конфронтация происходила не столько между учеными, сколько между властью и учеными. Тем не менее в 1920-х гг. в ситуации радикального переустройства общества эмпирические исследования и теория, укорененная в революционную реальность, все же находили свое развитие: например, «эмпириомонизм» А.А. Богданова [Kyзьминых 1992] и «социальная связь» А.С. Звоницкой ${ }^{11}$ [Голосенко, Зверев 1991]. В своих работах они искали возможность сочетания разнонаправленных интересов, разрешение конфликтов через различные способы объединения. К сожалению, результаты этих трудов, да и сами труды либо забыты, либо утрачены. Тогда же проводились исследования и прикладного характера, направленные на улучшение социалистической системы производства через рационализацию труда, и хотя работы Н.А. Витке ${ }^{12}$, Ф.Р. Дунаевского ${ }^{13}$ не были идеологическими, их выводы, тем не менее, остались проигнорированными властью, а сами ученые пропали без вести.

При этом следует отметить работу коллектива исследователей «Человек и его работа в СССР» (1968 г.), которые под научным руководством А.Г. Здраво-

\footnotetext{
11 Она вслед за Г. Дженнингсом считала, что формулу «стимул-реакция» следует расширить путем учета силы реакции других индивидов - то увеличивая, то блокируя личный «ответ-реакцию». Тем самым описывалось явление, которое позднее социологи и социальные психологи назовут установкой. У А.С. Звоницкой нет подобного термина, она использует другой - «социальная связь» как особое и очень сложное субъект-объектное отношение, частично охватывающее индивидуальное и коллективное сознание, частично реализующее себя в деятельности или общении людей [Голосенко, Зверев 1991, с. 76].

12 Витке Н.А. (2001) Организация управления и индустриальное развитие (Очерки по социологии научной организации труда и управления) // Кравченко А.И. (ред.) Антология социально-экономической мысли в России. 1920-1930-е гг. ХХ в. М.: Academia. С. 97-162.

13 Дунаевский Ф.Р. (2001) Комплексность в организации // Кравченко А.И. (ред.) Антология социально-экономической мысли в России. 1920-1930-е гг. ХХ в. М.: Academia. С. 163-224.
} 
мыслова и В.А. Ядова, изучали положение рабочих промышленных предприятий Ленинграда и детально проверяли тезисы марксистской теории об освобождении труда при социализме. Это была весьма успешная попытка соединить эмпирику с теорией - разработать чуткий инструментарий и проверить то, насколько идеи Маркса о возможной альтернативе капиталистической системе и преодолении отчуждения труда при социализме соответствуют действительности: было доказано, что материальные ценности не уходят, но становятся менее значимыми, а труд становится ценностью. Эти выводы не помешали исследователям выявить и различия в отношении к труду: например, ими фиксировалось влияние пола и возраста рабочих на удовлетворенность трудом и отмечалось гендерное неравенство, т.е. определенные пределы достижения равенства без учета индивидуальных (групповых) предпочтений и субъектного влияния на социальный процесс. Необходимо подчеркнуть, что исследовательский профессионализм не позволил ценностям и взглядам ученых-диссидентов проникнуть в исследование: профессиональное призвание оказалось выше идейных предпочтений, что позволило признать и опубликовать даже нежелательные результаты. Можно перечислить и другие качественные исследования: «Проблемы промышленной социальной психологии» А.А. Русалиновой (в сфере труда), «Современная семья и ее проблемы» А.Г. Харчева (в сфере семьи), «Использование совокупного времени общества» В.Д. Патрушева (в области бюджетов времени) и другие. Результаты этих изысканий, несомненно, являются достижением, их необходимо внести в копилку имеющегося багажа социологического знания XX в. и учитывать в дискуссиях как о практике реального социализма, так и о возможностях теоретической социологии в России [Здравомыслов 2010; Кирдина 2011].

Тем не менее исследований, посвященных анализу советского общества, явно не хватало: не изучались причины сохранения неравенства при реальном социализме; оставались без внимания мотивы скрытого недовольства преимуществами промышленных рабочих (высокой заработной платой, привилегиями при поступлении в вуз и т.д., причем очевидно недостаточных, чтобы изменить предвзятое отношение к физическому труду); не подвергалось критике ложное представление о завышенном и необоснованном вознаграждении за физический труд. До сих пор при сравнении положения советских рабочих и служащих акцент делается на разницу в зарплатах (низкую оплату врачей и учителей), но не принимается во внимание, что рабочие при относительно высокой заработной плате были ограничены в доступе к другим социальным благам по сравнению со специалистами и управленческими кадрами [Кротов, Буравой, Льтткина 2003]. На протяжении всего советского периода отсутствовали труды, объясняющие, к чему конкретно стремились советские женщины и насколько их желаниям соответствовали радикальные требования участниц диссидентского феминизма признать домашние обязанности работой.

И все же в отличие от первых американских социологов, защищавших интересы рынка и правящего класса, советские социологи сохранили критический взгляд на общество, на противоречивую позицию социолога и смогли поднять вопросы, поиск ответов на которые позволил бы, возможно, улучшить систему и найти компромисс. Но пример российской социологии в советский период демонстрирует, что система, не воспользовавшаяся объективными знаниями науки об обществе, которые предполагают совмещение разных перспектив и тщательную 
проверку предпочтений, «сама себя разрушила». Социология (как бы амбициозно это ни звучало) нужна для самого общества: умение «прислушиваться» к обществу способствует решению острых социальных вопросов, установлению компромисса между различными социальными группами, благоприятствует общественной стабильности. Когда объективное знание о системе в целом не учитывается, общество радикализируется. Оппозиция может выступать от имени угнетенных, однако следует учитывать, что интерес представительства бесправных становится понятным и проявляется тогда, когда есть обоснованное осознание происхождения социального неравенства. Как социология без общества невозможна, так и развитие общества без социологии маловероятно, и вся история советской социологии указывает на прямую связь и взаимозависимость между ними. Важно понимать, что социологическое знание необходимо для развития общества, что значимым условием признания социологов в обществе является поиск основания для соединения разных перспектив. Необходимо также принимать во внимание, что идеологизация науки сказалась на недостатке знаний, и вопрос о том, почему, при каких условиях это стало возможным в России, так и остался неизученным.

В итоге советское общество строилось без изучения последствий проводимой политики; менеджерами и экспертами становились представители партийной номенклатуры, далекие от социологического знания. Прежде часто признавалось, что советская социология носит лишь прикладной характер. Поскольку сегодня этот тезис вызывает сомнение, то высказывается и другое мнение: социология служанка идеологии и необходимо ее освобождение от государства. Обе позиции или крайности упрощают ситуацию, что проявляется в комментариях коллег [Алексеев, Демина 2015] или становится очевидным при сравнении с американской социологией.

\section{Социология в России без рабочего класса}

Исследования начала 1990-х гг. отличаются избыточным оптимизмом по поводу достаточно легкой смены одной нормативной системы другой, более идеальной. Несмотря на отсутствие теорий, способных объяснить суть трансформационных процессов, российские социологи пренебрегли изучением формирующихся практик, проистекающих социальных процессов и последствий проводимых рыночных реформ, при этом усилился скепсис в отношении марксизма, распределительной политики установления равенства, осуждались достижения реального социализма [Алашеев 1997; Темницкий 2004] ${ }^{14}$, идеализировалась роль рынка и индивидуального успеха и абсолютизировалась возможность субъектного действия, способного повлиять на производство властных отношений, а между тем эти вопросы требовали вдумчивого социологического исследования.

Оторванность российских социологов от реальной жизни обнаруживается и при анализе того, как проходили рыночные реформы в России 1990-х гг. и каким

14 И эта тенденция сохраняется, о чем свидетельствует ряд статей, приуроченных к столетию революции 1917 года в России и посвященных эффекту марксистской теории, а также переосмыслению значения социалистической революции [Черныли 2018; Горшков, Петухов 2018; Миронов 2018]. 
образом социология поддерживала этот процесс через рыночный фундаментализм, однозначную критику реального социализма и идеализацию капитализма. Социологическое обоснование преимуществ капитализма шло исключительно через идеологическую интерпретацию действительности как «возможности» без соотнесения с тем, кому реально они доступны и каковы последствия как внедрения, так и реализации рыночных проектов [Тихонова, Чепуренко 2004; Аврамова, Логинов 2002]. Поляризация в обществе связывалась с советским наследием, привычной зависимостью от государства и иждивенческими установками. В этих условиях разрабатывались новые подходы и стратегии социологического анализа - через призму автономного субъекта, режимов близости, повседневных порядков взаимодействия, ситуативного и эмоционального измерения неравенства, градообразующих систем ценностей и, соответственно, разных жизненных миров и представлений о справедливости и т.д. Увлеченные собой, очарованные безграничными возможностями новые мечтатели создавали ментальные схемы «идеального субъекта», нового человека и неугодного тоталитарного прошлого или идеального будущего, продвигали гибридные стратегии достижения справедливого общественного устройства. Экономисты зачастую оказывались более критичными к результатам рыночных реформ, но их скорее волновали жесткость трудового законодательства и его избирательное исполнение наряду с распространением неформальных отношений, нежели последствия увеличения гибкой занятости [Гимпельсон, Капелюшников 2005].

При социологическом изучении трудовых отношений акцент делался на адаптации к рынку, неформальных практиках, препятствующих рыночным преобразованиям, стратегиях выживания в условиях кризиса производства. Перспективы экономической реструктуризации производства ставились в прямую зависимость от поддержки преимуществ рыночной эконимики или учета коммуналистских ценностей [Шершнева, Фельдхов 1998]. Анализ ситуации на производстве или в целом на рынке труда связывался с особенностями (де)регулирования трудовых и экономических отношений [Олимпиева, Паченков 1999]. Редко этот процесс рассматривался исходя из перспективы рабочего класса. В качестве исключения можно сослаться на проекты ИСИТО под научным руководством С. Кларка [Кабалина, Кларк 1999] или исследования экономической инволюции под научным руководством М. Буравого [Буравой, Kротов 1992; Burawoy, Krotov, Lytkina 2000]. В целом следует признать, что снижение социального статуса рабочих произошло на фоне их стигматизации, приписывания им пассивности, безразличия и покорности [Трушков 2002].

Исследования авторов статьи совпали с переходом страны к рынку. В 1994 г. в своей кандидатской диссертации С.С. Ярошенко провела анализ существующих в социологической науке теорий воспроизводства бедности [Ярошенко 1994; Ярошенко 2006], обозначив самые значимые из них для понимания социальной природы бедности и наиболее существенные в описании и объяснении ее распространения в условиях капиталистической трансформации и репрезентативные для социологического анализа в исторической перспективе. Однако последующие работы, в которых она участвовала, показали разногласия между существующей теорией и практикой. Ее дальнейшие шаги в раскрытии причин постоянства бедности были связаны с установлением закономерных взаимосвязей между материальным благополучием, поведением индивида и состоянием социальной системы. 
Соединение теории с практикой развивались ею через изучение процесса взаимодействия структур возможностей (доступных в определенных позициях материальных благ), устойчивых практик их использования и достигаемого результата [Ярошенко 2005].

Со своей стороны, Т.С. Лыткина, изучая жизненные стратегии рабочих депрессивных предприятий, сформулировала теоретическое положение о трех взаимосвязанных детерминантах формирования экономического поведения: (1) внешних и (2) внутренних ресурсах, (3) потребностях индивидов. Под внешними ресурсами она понимала доступные блага, предоставляемые системой различным социальным группам, когда внешние возможности, будучи осознанными, становятся ресурсами конкретной социальной группы, и они могут быть использованы в удовлетворении потребностей. Потребности индивидов рассматривались как внутренний побудитель активности, отражающий нужду в чем-либо для поддержания жизнедеятельности социальной группы. Внутренние ресурсы индивидов предполагали определенный запас знаний, ценностей, опыта, средств, которые могут быть задействованы в процессе жизнеобеспечения. Также ею отмечалось, что преобладание внешней составляющей в формировании стратегий жизнеобеспечения рабочих настолько значимо, что возможности зачастую менее очевидны, чем существующие ограничения [Лыткина 2005; Лыткина 2011]. Далее наступает момент, когда сопротивляться рынку становится затруднительным, когда круг возможностей ограничен настолько, что наступает апатия, о которой писали еще авторы классического исследования «Мариенталь», проведенного в 1930 г. в одном из пригородов Вены коллективом австрийских социологов под руководством П. Лазарсфельда, М. Яходы и Г. Цайзеля [Lazarsfeld, Jahoda, Zeisel 1971/1933].

Постепенно для авторов статьи стало важным понять, каким образом в ходе освоения рыночных возможностей, в ситуации дефицита «хорошей работы» и продвижения идеологии индивидуального успеха, трансформируется советская распределительная система и действует режим исключения ${ }^{15}$. Если Т.И. Заславская пыталась понять, как сильноресурсные группы формируют правила игры в обществе [Заславская 2002], то для нас не менее важными являлись обнаружение «первых пострадавших» и определение того, каким образом их защитные или достижительские практики (практики повседневного использования доступных возможностей) вписываются в новые структуры действия и определяют вектор дальнейшего социально-экономического развития общества. Если по первой части (о значительном влиянии на процессы трансформации элит или сильноресурсных групп) были найдены единодушные точки зрения, то относительно «пострадавших» и их вклада в изменение структур неравенства мнения разделились. На результатах количественного исследования показано, что рабочие не только первыми испытали негативные последствия рыночного реформирования, но и оказались самой многочисленной группой среди крайне бедных [Ярошенко 2010].

\footnotetext{
15 На наш взгляд, понятие «исключение» обладает эвристическими возможностями для выявления действующих механизмов доминирования и извлечения прибыли. В отличие от категории «эксплуатации», которые предполагают присвоение прибыли определенными социальными классами, контролирующими процесс производства, исключение наиболее уместно к тем формам эксплуатации, которые только еще возникают (или остаются невидимыми).
} 
И все же не только авторы статьи фиксировали негативные последствия стремительного продвижения рыночных ценностей, отмечая недостаток исследований о положении рабочего класса. Находились и другие ученые, которые указывали на резкое ухудшение жизни рабочих и условий их труда, исчезновение рабочего класса как понятия и объекта исследования [Трушков 2002]. Некоторые из них, призывая создать идеологию рабочего класса [Беленький 2008], предполагали, что активность рабочего класса в борьбе за собственные интересы и результативность этой борьбы неизбежно способствовали бы повышению социального благополучия и наемных работников умственного труда [Трушков 2002]. Однако наши исследования показывали, что социальные связи распадаются, властные иерархии усиливаются, и на пересечении классовой, гендерной и гражданской позиций выстраивается жесткий распорядок доступа к ресурсам, необходимым для интеграции постсоветского общества [Лыткина 2001; Ярошенко 2004; Лыткина 2011; Ярошенко 2013]. Параллельно последние двадцать лет авторы наблюдали, как в процессы исключения вовлекаются все более широкие слои населения, охватывая сегодня и профессионалов [Льэткина (1) 2014; Льэткина (2) 2014].

Значимость самой социологии подвергалась трансформации - от взлета увлеченности предметом после советского застоя в сфере научного знания до постепенной утраты интереса к нему. На этом фоне развернулась борьба за наукометрические (в основном количественные) показатели публикационной активности, за возможности издания заказных статей на английском языке, которые затем учитывались в надбавках к зарплате. В свою очередь эти показатели становились индексами профессионализма российских ученых, хотя сами публикации к изучению российского общества были «привязаны» незначительно. Вместо социологии как призвания российские социологи обеспокоены сохранением своего профессионального статуса (по сути, реализуя ту же стратегию выживания, которую претворяли в жизнь рабочие в 1990-х гг.). И подобно тому, как навязывались обществу рыночные ценности, сегодня диктуются теории, созданные в ином контексте. То, что в действительности происходит в обществе, интересно не многим ученым, западные теории, плохо апробированные для России, продвигаются в качестве основного, если не единственного источника знаний. Малочисленные российские социологи вместо того, чтобы проявить солидарность и объединить усилия по сохранению своего профессионального сообщества в производстве знания, атомизируются и не ищут поддержки общества. Необоснованные амбиции российских социологов мешают им заняться исследованиями рабочего класса и обратиться к публичной социологии. Последняя воспринимается как второстепенная, как угроза профессионализму и альтернатива академической социологии, но в действительности задача публичных социологов более скромная - объединить усилия разных социологов и сплотить их с обществом в признании друг друга.

\section{К вопросу о трудящчихся классах, или о соцчиологах в поисках идентичности}

Текущее состояние российской социологии можно сравнить с американской в период ее становления, когда на передний план вышли продвижение ценностей рынка, представление о свободе выбора и рыночных возможностей. Однако сле- 
дует учесть существенное отличие: российские ученые, как и прежде, находятся в оппозиции государственной власти и продвигают социологию, отвернувшись от общества. Они не хотят уделять внимание проблемам рабочего класса, относить себя к числу трудящихся или оказаться в одних рядах с работниками наемного труда, что означало бы снижение статуса: для одних, интеллектуалов в первом поколении, зарабатывающих умственным трудом, - это возвращение к прежним позициям, для других, кто всегда пренебрегал рабочим классом, - нежелательное признание пролетариата. Тем не менее процессы, происходящие в мире, требуют обращения к рабочему классу или, по крайней мере, к трудящимся - работникам умственного и физического труда, работающим по найму.

В отличие от российских ученых, социологи других стран проявляют активный интерес проблемам трудящихся и последствиям глобализации рынка [Muraca 2012; Dorre 2014; Holdt 2014]. В «старых» странах Европейского Союза ведется дискуссия о работающих бедных, продвинутой маргинальности и способах ее регулирования [Bude 2000; Wacquant 2008; Bosch 2015]. В «новой», pacширившейся за счет посткоммунистических стран Европе беспокойство вызывает рост классификационной борьбы по этническому или гендерному признакам [Ladanyi, Szelenyi 2006]. В странах Латинской Америки исследователей тревожит положение неквалифицированных рабочих [Korzenievich, Smith 2000, p. 17]. По сути, социологи возвращаются к вопросам, которые волновали классиков социологии на заре капитализма - как описывать и объяснять меняющееся расколотое общество.

В ситуации трансформации глобального рынка труда меняется архитектура рабочих мест. Реструктуризация экономики имеет общемировые тенденции - размывание границ между производством и воспроизводством, повышение гибкости, дерегулирование трудовых отношений, освобождение работодателя и государства от ответственности за достойные условия труда. В промышленности сокращаются стабильные рабочие места с гарантиями и привилегиями, принятыми при фордистском, индустриальном режиме производства; расширяется рыночный сектор услуг с понижением заработной платы, сворачиванием гарантий и заключением срочных контрактов; растет число виртуальных рабочих мест; в новом сегменте занятости увеличивается риск уязвимости, или прекаризации [Стендинг 2014], хотя, безусловно, в гибкой занятости есть свои положительные стороны. Несмотря на критику теории прекариата, очевидно, что зона уязвимости работников расширяется и что опыт рабочего класса не принимается во внимание в исследованиях прекариата (шире - трудящихся). Товарно-денежные отношения проникают в сферу межличностного взаимодействия, когда образовательные и медицинские услуги, снабжение, ремонт, уборка помещений предполагают личные и часто неформальные договоренности по размеру и критериям оплаты. Иными словами, появляются новые субъекты трудовых отношений или происходит расширение рабочего класса за счет включения в оплачиваемую занятость новых видов работы, прежде «невидимой» или «бесплатной».

Следует подчеркнуть, что, со своей стороны, экономисты пытаются определить виды деятельности, которые связаны с «заботой»; для них важно вычислить объем часов, которые тратятся на оплачиваемую, бесплатную и общественную работу [Modorin 2014]. При этом явно не хватает социологических исследований, представляющих данные о реальном положении «неклассических» наемных 
работников и о том, как влияет прекарность (гибкие формы занятости) на условия труда, статус работника, карьерное продвижение и внутрифирменное взаимодействие. По-прежнему малочисленны работы о таких зонах уязвимости в пространстве возможностей, как прекарные домработницы или волонтеры общественных организаций. Наконец, остается много вопросов к тому, как рассогласованный статус наемного работника отражается на отношении к труду и кто в итоге может представлять интересы наемных работников и общества в целом.

Итак, история социологии показывает, что своим становлением она обязана рабочему классу, и сегодня, добившись успехов, она оказалась в ситуации, когда вновь должна вернуться к рабочему классу, но не только для получения знания об обществе, но и для того, чтобы найти у него поддержку. Масштабы недавних протестов против ужесточения трудового законодательства во Франции, референдум в пользу выхода из Евросоюза в Великобритании, рост националистических движений в Германии, сопротивление принятию беженцев из арабских и африканских стран в бывших постсоциалистических странах и т.д. - знаки того, что найденный компромисс между разными классами уже не действует, а для достижения нового требуется, кажется, невозможное - кооперация социологов для создания социологического знания, объясняющего рост социального неравенства в условиях глобализации.

\section{Вместо заключения: \\ о необходимости признания критической теории в России. «Умом Россию не понять»?}

История социологической мысли демонстрирует значимость категории рабочего класса для становления социологии и подтверждает тезис о необходимости обращения к рабочим. Современные реалии (в частности, российская ситуация) свидетельствуют об актуальности такого поворота и о наличии настоятельной потребности и запроса со стороны общества к социологии и социологам, обладающим особыми аналитическими инструментами и навыками, которые позволяют отслеживать и объяснять векторы социальных изменений, представлять общество как отдельную от экономики и политики сферу.

Анализ процессов, протекающих в обществе, через призму рабочего класса способствует сокращению противоречий и может быть полезен как при ревизии оснований социологического знания и реконструкции устаревших теорий, так и в разработке новых подходов. Сегодня необходимо такое знание об обществе, которое дает представление о цельности системы, или о том, какие возможности доступны исходя из определенной позиции, как и при каких условиях через действие сообществ воспроизводится или меняется структура неравенства. Отсюда возникают потребность в признании разных подходов и необходимость развития критического дискурса как внутри социологического сообщества, так за его пределами. Если в первом случае это напрямую связано с продвижением внутренней критики, то во втором - с публичной социологией и развитием изучаемых общностей. В качестве примера соединения разных подходов через их критическую оценку приведем три методологические разработки: феминистский анализ, социологи- 
ческий марксизм и теорию социального исключения. В разных вариациях они открывают значимые исследовательские перспективы и демонстрируют возможность теоретического прорыва в российской социологии.

Продуктивной является радикальная критика социологии представительницей феминистского анализа Д. Смит, которая обоснованно считает актуальным сегодня не столько сдвиг в субъекте, сколько формирование иной концепции социологии, нацеленной на осмысление опыта и условий его возникновения [Cмum 2014]. Исследуя субъектную позицию и используя актуальный опыт проживания в конкретном месте, Д. Смит анализирует внешние по отношению к субъекту формы социальной организации и тем самым раскрывает возможности и пределы автономии $^{16}$ [Smith 2005, pp. 9-13]. Такой подход позволяет вернуть в фокус внимания категорию рабочего класса и наполнить ее реальным содержанием исходя из текущих изменений. Говоря о классе, авторы настоящей статьи, вслед за Д. Смит, подразумевают некоторого рода отношения между работой, которую люди выполняют внутри или вне системы занятости, получаемой оплатой и приобретенными средствами существования (subsistence) [Smith 2009]. Социологический анализ положения рабочих (наемных работников) (и шире - трудящихся, занятых значимой деятельностью, на конкретном месте) позволит выявить современные противоречия между трудом и капиталом, а также каким образом в рассогласованной позиции обеспечивается благополучие. Иными словами, исходя того, как сами работники видят и представляют повседневную организацию взаимодействия с работодателями, коллегами по работе, родными, близкими и друзьями, какие предпринимают действия и как включаются в рыночный порядок (что делают и на что живут), возможна реконструкция устаревших категорий и концептов. Феминистский анализ отнюдь не ограничивается работой Д. Смит ${ }^{17}$. В целом феминистская критика как никакое другое социологическое направление способна обеспечить анализ причин роста социального неравенства и воспроизводства властных отношений в современных условиях, а также способствовать продвижению альтернативы доминирующим структурам и институтам, исходящей из конкретной позиции, которая связана с субъектным действием, ориентированным на равные отношения и на сопротивление подавлению.

Социологический марксизм, согласно которому «<..> необходимо уделять внимание продвижению альтернатив капитализму, так как конец капитализма не является внутренне присущей ему тенденцией. Теория социологического марксизма должна изучать опыт государственного социализма для понимания того, что следует избегать, а что может быть вполне приемлемым» [Буравой, Paйm 2011, с. 43]. Данный тезис развивает предыдущий методологический посыл, разворачивая настоящее действие в исторической перспективе, а также предполагает усиление

\footnotetext{
16 В качестве примера сошлемся на одно исследование, в котором исходной стала конкретная ситуация: выполнение школьных домашних заданий детьми совместно с родителями, являющимися одновременно членами родительского комитета и активистами соседского сообщества. Эта ситуация и опыт ее проживания являлись лишь начальной точкой для изучения институционального режима выполнения домашних заданий, которому подчинялись или противодействовали родители. Исходя из перспективы родителей и школьников, раскрывалась невидимая участникам организация отношений, в которой совместное выполнение домашних заданий не только становилось условием достижений в учебе и, соответственно, нормой среднего класса, но и женской работой и материнской обязанностью, с которой с трудом справлялись одинокие матери [Smith 2005, pp. 31-35].

17 Не менее интересны работы Н. Фрезер, А. Янг, Е. Фодор и других исследователей.
} 
эмансипационного влияния социологического знания. И здесь важно учитывать, что классовая позиция отличается возможностью контролировать свои производительные навыки (силы, собственность), отсюда возникает далеко не праздный, а насущный вопрос о том, как выстраивается такой контроль и кто именно извлекает прибыль из результатов труда. В узком смысле рабочий класс не контролирует рабочую силу и вынужден добровольно продавать ее на рынке труда. В широком смысле, когда любой труд становится одновременно товаром и значимой деятельностью, контроль над производительными навыками является спорной зоной и местом выстраивания новых границ между производством и воспроизводством, работой и домом. Насколько удастся представить процесс переформатирования отношений в этой сфере в социологических категориях, настолько будет разрешен вечный спор между марксизмом и феминизмом об источниках доминирования и соотношении разных форм власти.

Возможностный подход А. Сена применительно к проблематике социального исключения открывает еще одну перспективу и для объединения социологов, и для плодотворной дискуссии относительно возможностей в условиях рыночной глобализации [Сен 2004; Сен 2009]. Согласно этому подходу, исключение трактуется как ограничение возможностей заниматься значимой деятельностью и самостоятельно управлять личной жизненной ситуацией. Тем самым сторонники данного подхода стремятся учесть ценные для нас аргументы исходя не из инструментальной рациональности или расчета наиболее эффективных средств достижения желаемого, а через критический анализ значимых действий и достигаемой с их помощью свободы. Для социологов возможностный подход открывает перспективу критической оценки того, как и при каких условиях имеющиеся возможности или активы переводятся в значимую деятельность, способствуют накоплению ресурсов у одних и сокращению у других. В принципе, расширительное толкование уязвимости может стать продуктивным, если в понятие «уязвимость» будут включены вопросы о «переговорах» относительно труда, его оплаты, форм вознаграждения и достигаемого результата. В условиях глобализации рынка меняется граница между сферами производства и воспроизводства, а вопросы экономического (классового, производственного, внешне ненасильственного изъятия прибавочной стоимости) и внеэкономического (статусного, насильственного) принуждения в трансформации капитализма становятся особенно острыми. Игнорируя одни механизмы социального исключения (лишения современных средств существования) за счет продвижения других (статусного принуждения), каждая из сторон совершают одну и ту же ошибку.

Исследования в рамках предлагаемых направлений социологического анализа, безусловно, могут быть отражены в задачах публичной социологии. Но следует осознавать, что если прежде рабочий класс выступал агентом социальных преобразований в реализации общечеловеческих ценностей, то теперь необходимо переосмысление того, как снижение статуса влияет на «переговоры» о вознаграждении, на координацию действий для преодоления неравенства (властных отношений), и каким образом меняется представление о возможностях кооперации разных сторон. Задача публичной социологии не только призывать к представительству интересов отличных от академической аудитории общностей (независимо от того, какую часть трудящихся данные общности представляют), но и мобилизовать усилия в определении обстоятельств, выталкивающих их из современного постсоци- 
алистического общества и при каких условиях возможна интеграция. Иными словами, в настоящий момент существует настоятельная потребность на включение низового опыта и субъективной позиции для развития альтернативного подхода в социологии с учетом накопленных результатов социологического изучения рабочего класса.

На наш взгляд, социология для трудящихся классов не только возможна, но и необходима для развития самой социологии. Именно благодаря обращению ученых к проблемам рабочего класса стало реальным становление социологии как науки. Как бы ни были амбициозны замыслы классиков социологии относительно формирования идеального (справедливого) общества, очевидным остается факт, что если какой-то науке и суждено его изучать, менять и совершенствовать, то именно социологии в любых ее проявлениях: академической, критической, прикладной и публичной.

\section{Литература}

Аврамова Е.М., Логинов Д.М. (2002) Социально-экономическая адаптация: ресурсы и возможности // Общественные науки и современность. № 5. С. 24-34.

Алашеев С. (1997) О любви особого рода и специфике советского производства // Социологический журнал. № 1/2. С. 169-182.

Алексеев А., Демина Н. (2015) Кому и зачем нужна социология в России // Троицкий вариант - Наука. № 185. С. 5-6.

Беленький В.Х. (2008) К вопросу об идеологии рабочего класса // Социологические исследования. № 12. С. 72-79.

Буравой М. (1991) Развитие американской социологии: дилеммы институционализации и профессионализации // Рубеж. Альманах социальных исследований. № 1. С. 74-95.

Буравой М. (2000) Великая инволюция: Реакция России на рынок // Рубеж. № 15. С. 5-35.

Буравой М. (2007) Публичная социология прав человека // Журнал социологии и социальной антропологии. № 2. С. 27-44.

Буравой М. (2008) За публичную социологию // Ярская-Смирнова Е., Романов П. (ред.) Социальная политика современной России: реформы и повседневность. М.: ЦСПГИ, Вариант. С. 8-51.

Буравой М., Кротов П. (1992) Советский вариант перехода к капитализму // Рубеж. Альманах социальных исследований. № 4. С. 107-139.

Буравой М., Райт Э.О. (2011) Социологический марксизм // Социология. № 2. С. 43-57.

Вудс А., Грант Т. (2015) Бунтующий разум. Марксистская философия и современная наука. М.: Канон+.

Гимпельсон В., Капелюшников Р. (2005) Нестандартная занятость и российский рынок труда. Препринт WP3/2005/05. М.: ВШЭ.

Голосенко И.А. (1995) К портрету русского социолога // Рубеж. Альманах социальных исследований. № 6-7. С. 3-11.

Голосенко И.А. (2002) Социологическая ретроспектива дореволюционной России. СПб.: Социологическое общество им. М.М. Ковалевского.

Голосенко И.А., Зверев В.М. (1991) Социолог Агнесса Звоницкая: работы и судьба // Социологические исследования. № 2. С. 75-81.

Горшков М.К., Петухов В.В. (2018) Октябрьская революция 1917 г. и ее последствия в восприятии современных россиян // Социологические исследования. № 1. С. 6-18.

Заславская Т.И. (2002) Социетальная трансформация российского общества. М.: Дело.

Здравомыслов А.Г. (2010) Сравнительный анализ национальных социологических школ в их отношении к национальным культурам // Вестник Института социологии. № 1 . C. 179-202. 
Здравомыслов А.Г., Ядов В.А. (2003) Человек и его работа в СССР и после. М.: Аспект Пресс.

Кабалина В.И. (ред.) (2008) Социальные режимы постсоветского производства. Сыктывкар: Коми НЦ УрО РАН.

Кабалина В.И., Кларк С. (ред.) (1999) Занятость и поведение домохозяйств: адаптация к условиям перехода к рыночной экономики в России. М.: РОССПЭН.

Кабо Е.О. (1928) Очерки рабочего быта. Опыт монографического исследования домашнего рабочего быта. М.: Книгоиздательство ВЦСПС.

Кирдина С.Г. (2011) Интеллектуальный шанс России // Социологические исследования. № 1. C. $5-10$.

Кирдина С.Г. (2016) О некоторых проблемах социологического дискурса // Социологические исследования. № 3. С. 148-153.

Кларк С. (1992) Был ли Ленин марксистом? Народнические корни марксизма-ленинизма // Рубеж. Альманах социальных исследований. № 3. С. 53-78.

Ковалев А.Д. (1994) Эволюционная социология Г. Спенсера. Первый опыт системного подхода // Давыдов Ю.Н. (ред.) Очерки по истории теоретической социологии XIX века. М.: Наука. С. 97-134.

Кротов П., Буравой М., Лыткина Т. (2003) Жилищная стратификация города: эволюция советской модели. Сыктывкар: Коми научный центр УрО РАН.

Кузьминых Н.А. (1992) Архитектор «нового мира». К биографии Александра Богданова // Социологический журнал. № 12. С. 58-78.

Лапин Н.И. (2004) Эмпирическая социология в Западной Европе. М.: ВШЭ.

Лыткина Т. (2001) Распределение власти в семье как фактор стратегии занятости и организации домохозяйства // Рубеж. Альманах социальных исследований. № 16-17. C. $50-65$.

Лыткина Т. (2005) Экономическое поведение «новых бедных» в условиях социальной трансформации. Диссертация на соискание степени кандидата социологических наук. М.: ИС РАН.

Лыткина Т. (2011) Социальная биография исключения в постсоветской России // Журнал социологии и социальной антропологии. Т. 14. № 1. С. 87-109.

Лыткина Т. (1) (2014) Социальный потенциал северного города: от игнорирования к признанию // Журнал социологии и социальной антропологии. Т. 17. № 3. С. 33-47.

Лыткина Т. (2) (2014) Человек на Севере после распада СССР: от признания к игнорированию // Известия Коми научного центра УрО РАН. № 3. С. 144-151.

Миронов Б.Н. (2017) Рабочие в революции 1917 г.: субъект истории или пушечное мясо? // Социологические исследования. № 2. С. 24-35

Олимпиева И., Паченков О. (ред.) (1999) Неформальная экономика в постсоветском пространстве. Проблемы исследования и регулирования. СПб.: ЦНСИ.

Райт Э. (1995) Проблема классов в современной социологии // Рубеж. Альманах социальных исследований. № 6-7. С. 143-164.

Райт Э. (1996) Происхождение капитализма // Рубеж. Альманах социальных исследований. № 8-9. C. 49-59.

Сен А. (2004) Развитие как свобода. М.: Новое издательство.

Сен А. (2016) Идея справедливости. М.: Издательство Института Гайдара.

Смит Д. (2014) Женская перспектива как радикальная критика социологии // Гендерный маршрут // http://gender-route.org/articles/feminism/zhenskaya_perspektiva kak_radikal_naya_kritika_sociologii/

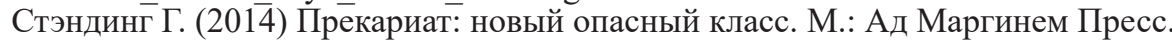

Темницкий А.Л. (2004) Ориентации рабочих на патерналистские и партнерские отношения с руководством // Социологические исследования. № 6. С. 26-37.

Тихонова Н.Е., Чепуренко А.Ю. (2004) Предпринимательский потенциал российского общества // Мир России. № 1. С. 116-145.

Трушков В.В. (2002) Современный рабочий класс России в зеркале статистики // Социологические исследования. № 2. С. 45-51.

Черныш М.Ф. (2018) Современный марксизм в мировом и российском контекстах // Социологические исследования. № 5. С. 15-25. 
Шершнева Е.Л., Фельдхоф Ю. (1999) Культура труда в процессе социально-экономических преобразований: опыт эмпирического исследования на промышленных предприятиях России. СПб.: Петрополис.

Юкина И. (2007) Русский феминизм как вызов современности. СПб.: Алетейя.

Ярошенко С. (1994) Проблематика субкультуры бедности в американской социологии: эволюция принципов исследования и подходов. Диссертация на соискание степени кандидата социологических наук. М.: ИС РАН.

Ярошенко С.С. (2004) Северное село в режиме социального исключения // Социологические исследования. № 7. С. 71-82.

Ярошенко С.С. (2005) Бедность в постсоциалистической России. Сыктывкар: Коми научный центр УрО Российской АН.

Ярошенко С.С. (2006) Четыре социологических объяснения бедности // Социологические исследования. № 7. С. 71-83.

Ярошенко С.С. (2010) Новая бедность в России после социализма // Laboratorium. № 3. C. $42-72$.

Ярошенко С.С. (2013) Женская работа и личное благополучие. Технологии исключения в постсоветской России // Экономическая социология. Т. 14. № 5. С. 23-59.

Bosh G. (2015) Shrinking Collective Bargaining Coverage, Increasing Income Inequality: A Comparison of five EU Countries // International Labour Review, vol. 154, no 1, pp. 57-66.

Bude H., Willisch A. (2006) Das Problem der Exklusion // Das Problem der Exklusion. Ausgegrenzte, Entbehrliche, Überflüssige (eds. Bude H., Willisch A.), Hamburg: Hamburger Edition, pp. 7-26.

Burawoy M. (2005) For Public Sociology // American Sociological Review, no 70, pp. 4-28.

Burawoy M., Krotov P., Lytkina T. (2000) Domestic Involution: How Women Organize Survival in a North Russian City // Russia in the New Century: Stability or Disorder? (eds. Bonnel V., Breslauer G.), Boulder Co.: Westview Press, pp. 231-257.

Dorre R. (2014) Public Sociology - a Concept for Labour Research. WP DFG. № 9/ 2014, Jena.

Holdt K. (2014) Critical Engagement in Fields of Power: Cycles of Sociological Activism in Post-apartheid South Africa // Current Sociology, vol. 62, no 2, pp. 181-196.

Korzenievich R.P., Smith W.S. (2000) Poverty, Inequality and Growth in Latin America: Searching for the High Road to Globalization // Latin America Research Review, vol. 35, no 3, pp. 7-54.

Ladanyi J., Szelenyi I. (2006) Patterns of Exclusion: Constructing Gypsy Ethnicity and the Making of an Underclass in Transitional Societies of Europe, New York: Columbia University press.

Lazarsfeld P.F., Jahoda M., Zeisel H. (1971 [1933]) Marienthal. The Sociography of Unemployed Community, Chicago: Aldine, Atherton.

Modorin M. (2014) Care Economy in Switzerland. Exploring the Economic Relationship between Care Economy and Sustainable Economy // Sustainable Economy and Green Growth: Who Cares, Berlin, pp. 26-31.

Muraca B. (2012) Towards a Fair Degrowth-society: Justice and the Right to a 'Good Life' Beyond Growth // Futures, no 44, pp. 535-545.

Smith D.E. (1988) The Everyday World as Problematic. A Feminist Sociology, Milton Keynis: Open University Press.

Smith D.E. (2005) Institutional Ethnography: A Sociology for People, Toronto: AltaMira Press.

Smith D.E. (2009) Categories Are Not Enough // Gender and Society, vol. 23, no 1, pp. 76-80.

Wacquant L. (2008) Urban Outcasts. A Comparative Sociology of Advanced Marginality, Malden: Polity Press. 


\title{
Is Sociology for the Working Classes Possible Today?
}

\author{
T. LYTKINA*, S. YAROSHENKO**
}

\begin{abstract}
*Tat'yana Lytkina - PhD in Sociology, Senior Researcher, Institute of Social-economic and Power Problems of the North. Address: 26, Kommunisticheskaya St., Syktyvkar, 167982, Russian Federation. E-mail: tlytkina@yandex.ru

$* *$ Svetlana Yaroshenko - PhD in Sociology, Assistant Professor, Chair of Comparative Sociology, Faculty of Sociology, St. Petersburg State University. Address: 1/3, Smolnogo St., Saint Petersburg, 191124, Russian Federation. E-mail: svetayaroshenko@gmail.com
\end{abstract}

Citation: Lytkina T., Yaroshenko S. (2019) Is Sociology for the Working Classes Possible Today? Mir Rossii, vol. 28, no 1, pp. 101-123 (in Russian). DOI: $10.17323 / 1811-038 X-2019-28-1-101-123$

\begin{abstract}
This article scrutinizes the efficiency of the sociology which studies social inequality from the perspective of the working class, i.e. the class that is forced to sell its labor against a backdrop of declining social status. By drawing on the history of sociology, the author examines the significance of the notion of 'working class' for the development of sociological science. The thesis is also evaluated in the context of pre-Revolutionary and Soviet sociology, and the author highlights a particular feature of Russian sociology in general, i.e. the confrontation between the state and social researchers. It is argued that that societal evolution could hardly have been possible without sociology and that sociology itself cannot evolve without engagement on behalf of society and without public knowledge about the mechanisms of class formation. Current developments in Russian sociology are defined as involutional with Russian sociologists growing more isolated and too narrowly focused on their concerns and controversies. Their sociology tends to neglect worker interests in spite of the global search for consensus among various social classes in the context of market globalization. The authors also argue that analyzing social processes from a working class perspective effectively contributes to diminishing social tensions and can also be useful for the critical assessment of the foundations of sociological knowledge, the reconstruction of outdated theories, and the development of new approaches. They argue for new knowledge about society, which must consider society's integrality as a system and provide an understanding of how it reproduces or changes its structure through the agency of social groups. Finally, they emphasize the demand for the acknowledgement of different approaches in sociology and the necessity for critical discourse both inside and outside the sociological community. The former is connected directly to the joint efforts of sociologists in advancing inner critique; the latter - with public sociology and the evolution of social classes.
\end{abstract}

Key words: working class, laboring class, critical sociology, public sociology, feminist analysis, sociological Marxism, theory of social exclusion 


\section{References}

Avramova E.M., Loginov D.M. (2002) Sotsial'no-economicheskaya adaptaziya: resursy i vozmozhnosty [Socio-economic Adaptation: Resources and Opportunities]. Obshchestvennye nauki i sovremennost', no 5, pp. 24-34.

Alasheev S. (1997) O lubvi osobogo roda i spezifike sovetskogo proisvodstva [On the Particular Kind of Love and the Specificity of the Soviet Production]. Sotsiologicheskij zhurnal, no $1 / 2$, pp. 169-182.

Alekseev A., Demina N. (2015) Komu i zachem nuzhna sociologiya v Rossii [Who Needs Sociology in Russia and Why?]. Troiskij variant - Nauka, no 185, pp. 5-6.

Belen'kij V.Kh. (2008) K voprosu ob ideologii rabochego klassa [On the Question of the Ideology of the Working Class]. Sotsiologicheskie issledovaniya, no 12, pp. 72-79.

Bosh G. (2015) Shrinking Collective Bargaining Coverage, Increasing Income Inequality: A Comparison of five EU Countries. International Labour Review, vol. 154, no 1, pp. 57-66.

Bude H., Willisch A. (2006) Das Problem der Exklusion. Das Problem der Exklusion. Ausgegrenzte, Entbehrliche, Überflüssige (eds. Bude H., Willisch A.), Hamburg: Hamburger Edition, pp. 7-26.

Burawoy M. (1991) Razvitie amerikanskoj sotsiologiyi: dilemmy instituzionalizatsii i professionalizatsii [The Development of American Sociology: Dilemmas of Professionalization and Institutionalization]. Rubezh. Almanakh sotsial'nykh issledovanij, no 1, pp. 74-95.

Burawoy M. (2000) Velikaya involuziya: Reakziya Rossii na rynok [The Great Involution: Russia's Response to the Market]. Rubezh. Almanakh sotsial'nykh issledovanij, no 15, pp. 5-35.

Burawoy M. (2005) For Public Sociology. American Sociological Review, no 70, pp. 4-28.

Burawoy M. (2007) Publichnaya sotsiologiya prav cheloveka [Public Sociology for Human Rights]. Zhurnal sotsiologii i sotsial'noj antropologii, no 2, pp. 27-44.

Burawoy M. (2008) Za publichnuyu sotsiologiyu [For Public Sociology]. Sotsial'naya politika sovremennoj Rossii: reformy i povsednevnost' [Social Policy in Contemporary Russia: Reforms and Everyday Life] (eds. Yarskaya-Smirnova E., Romanov P.), Moscow: ZSPGI, Variant, pp. 8-51.

Burawoy M., Krotov P. (1992) Sovetskyj variant perekhoda k kapitalizmu [The Soviet Transition from Socialism to Capitalism]. Rubezh. Almanakh sotsial'nykh issledovanij, no 4, pp. 107-139.

Burawoy M., Krotov P., Lytkina T. (2000) Domestic Involution: How Women Organize Survival in a North Russian City. Russia in the New Century: Stability or Disorder? (eds. Bonnel V., Breslauer G.), Boulder Co.: Westview Press, pp. 231-257.

Burawoy M., Wright E.O. (2011) Sotsiologicheskyj marksism [Sociological Marxism]. Sotsiologiya, no 2, pp. 43-57.

Chernysh M.F. (2018) Sovremennyi Marxism v mirovom i rossijskom kontexte [Marxism in the Global and Russian Contexts]. Sotsiologicheskie issledovaniya, no 5, pp. 15-25.

Clarke S. (1992) Byl li Lenin marksistom? Narodnicheskie korni marksisma-leninisma [Was Lenin a Marxist? The Populist Roots of Marxism-Leninism]. Rubezh. Almanakh sotsial'nykh issledovanij, no 3, pp. 53-78.

Dorre R. (2014) Public Sociology - a Concept for Labour Research. WP DFG. No 9/ 2014, Jena.

Gimpelson V., Kapelushnikov R. (2005) Nestandartnaya zanyatost' $i$ rossijskyj rynok [Non-standard Employment and the Russian Market]. Preprint WP3/2005/05, Moscow: HSE.

Golosenko I.A. (1995) K portretu russkogo sotsiologa [To the Portrait of Russian Sociologist]. Rubezh. Almanakh sotsial'nykh issledovanij, no 6-7, pp. 3-11.

Golosenko I.A. (2002) Sotsilogichaskaya retrospektiva dorevolzionnoj Rossii [Sociological Retrospective of Pre-revolutionary Russia], Saint Petersburg: Socilogicheskoe obshchestvo im. M.M. Kovalevskogo.

Golosenko I.A., Zverev V.M. (1991) Sociolog Agnessa Zvonitskaya: raboty i sud'ba [Sociologist Agnes Zvonitskaya: Work and Destiny]. Sotsiologicheskie issledovaniya, no 2, pp. 75-81.

Gorshkov M.K., Petukhov V.V. (2018) Oktyabr'skaya revolyutsiya 1917 goda i ee posledstviya v vospriyatii sovremennykh rossiyan [The October Revolution of 1917 and its Aftermath in the Public Perception of Modern Russians]. Sotsiologicheskie issledovaniya, no 1, pp. 6-18.

Holdt K. (2014) Critical Engagement in Fields of Power: Cycles of Sociological Activism in Post-apartheid South Africa. Current Sociology, vol. 62, no 2, pp. 181-196. 
Kabalina V.I., Clark S. (eds.) (1999) Zanyatost'i povedenie domokhozyajstv: adaptaziya k usloviyam perekhoda krynochnoj ekonomike v Rossii [Employment and Household Behavior: Adaptation to the Transition to a Market Economy in Russia], Moscow: ROSSPEN.

Kabalina V.I. (ed.) (2008) Sotsial'nye regimy postsovetskogo proizvodstva [Social Regimes of Post-Soviet Production], Syktyvkar: Komi NZ UrO RAN.

Kabo E.O. (1928) Ocherki rabochego byta. Opyt monograficheskogo issledovaniya domashnego rabochego buta [Essays on Working Life. A Monographic Study of Worker's Home Life], Moscow: Knigoizdatelstvo VZSPS.

Kirdina S.G. (2011) Intellektual'nuj shans Rossii [The Intellectual Chance for Russia]. Sotsiologicheskie issledovaniya, no 1, pp. 5-10.

Kirdina S.G. (2016) O nekotorykh problemakh sotsiologicheskogo diskursa [On Some Problems of Sociological Discourse]. Sotsiologicheskie issledovaniya, no 3, pp. 148-153.

Kovalev A.D.(1994) Evoluzionnaya sotsiologiya G. Spenser. Pervyj opyt sistemnogo podkhoda [The Evolutionary Sociology of G. Spencer. The First Experience of a Systematic Approach]. Ocherki po istorii teoreticheskoj sotsiologii XIX veka [Essays on the History of Theoretical Sociology of the XIX Century] (ed. Davydov Yu.N.), Moscow: Nauka, pp. 97-134.

Krotov P., Burawoy M., Lytkina T. (2003) Zhilishchnaya stratifikatsiya goroda: evolutsiya sovetskoj modeli [Housing Stratification of the City: the Evolution of the Soviet Model], Syktyvkar: Komi nauchnyi zentr UrO RAN.

Korzenievich R.P., Smith W.S. (2000) Poverty, Inequality and Growth in Latin America: Searching for the High Road to Globalization. Latin America Research Review, vol. 35, no 3, pp. 7-54.

Kuzminykh N.A. (1992) Arkhitektor «novogo mira». K biografii Alexandra Bogdanova [The Architect of the "New World". To the Biography of Alexander Bogdanov]. Sotsiologicheskij zhurnal, no 12, pp. 58-78.

Ladanyi J., Szelenyi I. (2006) Patterns of Exclusion: Constructing Gypsy Ethnicity and the Making of an Underclass in Transitional Societies of Europe, New York: Columbia University press.

Lapin N.I. (2004) Empiricheskaya sotsiologiya v Zapadnoj Evrope [Empirical Sociology in Western Europe], Moscow: HSE.

Lazarsfeld P.F., Jahoda M., Zeisel H. (1971 [1933]) Marienthal. The Sociography of Unemployed Community, Chicago: Aldine, Atherton.

Lytkina T. (2001) Raspredelenie vlasti v sem'e kak factor strategii zanyatosti i organizatsii domokhozajstva [Distribution of Power in the Family as a Factor in the Employment Strategy and Organization of the Household]. Rubezh. Almanakh sotsial'nykh issledovanij, no 16-17, pp. 50-65.

Lytkina T. (2005) Ekonomicheskoe povedenie «novykh bednykh» v usloviyakh sotsial'noj transformatsii [Economic Behavior of the "New Poor" in the Conditions of Social Transformation], Moscow: IS RAN.

Lytkina T. (2011) Sotsial'naya biografiya isklyucheniya v postsovetskoj Rossii [The Social Biography of Exclusion in Post-Soviet Russia]. Zhurnal sotsiologii i sotsial'noj antropologii, vol. 14, no 1, pp. 87-109.

Lytkina T. (1) (2014) Sotsial'nyj potentsial severnogo goroda: ot ignorirovaniya k priznaniyu [The Social Potential of the Northern City: from Ignoring to Recognition]. Zhurnal sotsiologii $i$ sotsial'noj antropologii, vol. 17, no 3, pp. 33-47.

Lytkina T. (2) (2014) Chelovek na Severe posle raspada SSSR: ot priznaniya k ignorirovaniyu [Man in the North after the Collapse of the USSR: from Recognition to Ignoring]. Izvestiya Komi nauchnogo zentra UrO RAN, no 3, pp. 144-151.

Mironov B.N. (2017) Rabochie v revolyutsii 1917 g.: sub'ekt istorii ili pushechnoe myaso? [Russian Workers in the 1917 Revolution: the Subject of History or Cannon Fodder?]. Sotsiologicheskie issledovaniya, no 2, pp. 24-35.

Modorin M. (2014) Care Economy in Switzerland. Exploring the Economic Relationship between Care Economy and Sustainable Economy. Sustainable Economy and Green Growth: Who Cares, Berlin, pp. 26-31.

Muraca B. (2012) Towards a Fair Degrowth-society: Justice and the Right to a 'Good Life' Beyond Growth. Futures, no 44, pp. 535-545.

Olimpieva I., Pachenkov O. (eds.) (1999) Neformal'naya ekonomika v postsovetskom prostranstve. Problemy issledovaniya i regulirovaniya [Informal Economy in the Post-Soviet Space. Problems of Research and Regulation], Saint Petersburg: ZNSI. 
Sen A. (2016) Idea spravedlivosti [The Idea of Justice], Moscow: Izdatel'stvo Instituta Gaidara. Sen A. (2004) Razvitie kak svoboda [Development as Freedom], Moscow: Novoye izdatelstvo.

Shershneva E.L., Feldholf J. (1999) Kultura truda v protsesse sotsial'no-ekonomicheskikh preorazovanij: opyt empiricheskogo issledovaniya na promyshlennykh predpriatiyakh Rossii [Culture of Work in the Process of Socio-economic Transformation: the Experience of Empirical Research at Industrial Enterprises in Russia], Saint Petersburg: Petropolis.

Smith D.E. (1988) The Everyday World as Problematic. A Feminist Sociology, Milton Keynis: Open University Press.

Smith D.E. (2005) Institutional Ethnography: A Sociology for People, Toronto: AltaMira Press.

Smith D.E. (2009) Categories Are Not Enough. Gender and Society, vol. 23, no 1, pp. 76-80.

Smith D.E. (2014) Zhenskaya perspektiva kak radikal'naya kritika sotsiologii [Women's Perspective as a Radical Critique in Sociology]. Gendernyj marshrut. Available at: http://gender-route.org/articles/feminism/zhenskaya_perspektiva_kak_radikal_naya_ kritika_sociologii/, accessed 20.01.2019.

Standing G. (2014) Prekariat: novyj opasnyj klass [The Precariat: The New Dangerous Class], Moscow: Ad Marginem Press.

Temnitskiy A.L. (2004) Orientasia rabochih na paternalistskie i partnerskie otnoshenia s rukovodstvom [Orientation of Workers Towards Paternalistic and Partnership Relations with Management]. Sotsiologicheskie issledovaniya, no 6, pp. 26-37.

Tikhonova N.E., Chepurenko A.Y. (2004) Predprinimatel'skyj potentsial rossijskogo obshchestva [Entrepreneurial Potential of Russian Society]. Mir Rossii, no 1, pp. 116-145.

Trushkov V.V. (2002) Sovremennyj rabochij klass Rossii v zerkale statistiki [The Modern Working Class in Russia in the Mirror of Statistics]. Sotsiologicheskie issledovaniya, no 2, pp. 45-51.

Wacquant L. (2008) Urban Outcasts. A Comparative Sociology of Advanced Marginality, Malden: Polity Press.

Woods A., Grant T. (2015) Buntuyushchij razum. Marksistskaya filosofiya i sovremennaya nauka [Revolting Consciousness: Marxist Philosophy and Modern Science], Moscow: Kanon+.

Wright E. (1995) Problemy klassov v sovremennoj sotsiologii [The Problem of Classes in Modern Sociology]. Rubezh. Almanakh sotsial'nykh issledovanij, no 6-7, pp. 143-164.

Wright E. (1996) Proishozhdenie kapitalisma [Origins of Capitalism]. Rubezh. Almanakh sotsial'nykh issledovanij, no 8-9, pp. 49-59.

Yaroshenko S. (1994) Problematika subkultury bednosti v amerikanskoj sotsiologii: evolutsiya prinzipov issledovaniya i podkhodov [The Problem of the Subculture of Poverty in American Sociology: the Evolution of Research Methods and Approaches], Moscow: IS RAN.

Yaroshenko S. (2004) Severnoe selo v rezhime sotsial'nogo isklucheniya [The Northern Village in the Regime of Social Exclusion]. Sotsiologicheskie issledovaniya, no 7, pp. 71-82.

Yaroshenko S. (2005) Bednost'v postsotsialisticheskoj Rossii [Poverty in Post-socialist Russia], Syktyvkar: Komi nauchnyi zentr UrO RAN.

Yaroshenko S.S. (2006) Chetyre sotsiologicheskikh ob'yasneniya bednosti [Four Sociological Explanations of Poverty]. Sotsiologicheskie issledovaniya, no 7, pp. 71-83.

Yaroshenko S. (2010) Novaya bednost' v Rossii posle sotsialismf ["New Poverty" in Russia after Socialism]. Laboratorium, no 3, pp. 42-72.

Yaroshenko S.S. (2013) Zhenskaya rabota i lichnoe blagopoluchie. Tekhnologii isklucheniya v postsovetskoj Rossii [Women's Work and Personal Well-being. Technology of Exclusion in Post-soviet Russia]. Ekonomicheskaya sotsiologiya, vol. 14, no 5, pp. 23-59.

Yukina I. (2007) Russkij feminism kak vysov sovremennosti [Russian Feminism as a Challenge to Modernity], Saint Petersburg: Aleteya.

Zaslavskaya T.I. (2002) Sotsietal'naya transformaziya rossijskogo obshchestva [Societal Transformation of Russian Society], Moscow: Delo.

Zdravomyslov A.G. (2010) Sravnitelnyj analis nazional'nykh sotsiologicheskikh shkol v ikh otnoshenii k nazional'nym kul'turam [The Comparative Analysis of National Sociological Schools in Their Relation to National Cultures]. Vestnik Instituta sotsiologii, no 1, pp. 179-202.

Zdravomyslov A.G., Yadov V.A. (2003) Chelovek $i$ ego rabota $v$ SSSR $i$ posle [The Man and His Work in USSR and After], Moscow: Aspekt Press. 